\title{
Risk Assessment in Energy Trace and Barrier Analysis using TOPSIS in Steelmaking plant of Iran National Steel Industrial Group
}

\author{
Somayeh Behbahani ${ }^{1}$, Soolmaz Dashti ${ }^{2, *}$ \\ ${ }^{1}$ Department of Environmental Management, Ahvaz Branch, Islamic Azad University, Ahvaz, Iran \\ 2 Assistant Professor, Department of Environment, Ahvaz Branch, Islamic Azad University, Ahvaz, Iran \\ * Corresponding Author: Soolmaz Dashti, Department of Environment, Ahvaz Branch, Islamic Azad University, Ahvaz, Iran. \\ Email: soolmazdashti@iauahvaz.ac.ir; solmazdashti@gmail.com
}

Received: $19 / 12 / 2017$

Accepted: 03/11/2018

How to Cite this Article:

Behbahani S, Dashti S. Risk Assessment in Energy Trace and Barrier Analysis using TOPSIS in Steelmaking plant of Iran National Steel Industrial Group. $J$ Occup Hyg Eng. 2018; 5(3): 2534. DOI: 10.21859/johe.5.3.25

\begin{abstract}
Background and Objective: Steel manufacturing industry is one of the most dangerous industries worldwide because the steel mill workers are vulnerable to a big deal of hazards regarding the job nature. This study evaluated the risk levels in the steel manufacturing unit of Iran National Steel Industrial Group in 2017.

Materials and Methods: Energy trace and barrier analysis were used in order to identify the risks.

The data were collected with the help of observation, interviews with workers and experts, questionnaires as well as accidents records in the safety unit. Pairwise Comparison was done and the probability of occurrence of various risk factors was determined by "Fuzzy analytical hierarchy process solver". The obtained score was considered as the risk occurrence probability value. The incident intensity and the controlling systems were also scored. Then, the risks were prioritized based on three factors, namely incident intensity, the probability of occurrence, and control systems using "BT TOPSIS Solver".

Results: According to the results, 27 risk factors were specified in terms of safety, health, and the environment. Exposure to the molten materials and gas consumption were ranked the highest $(0.9001)$ and lowest $(0.0263)$, respectively. In addition, the results were categorized based on four risk levels of the high (44\%), serious (41\%), and medium and low (15\%).

Conclusion: The most important sorts of energies in steelmaking plant are chemical, heat, and potential. With regard to the risk assessment, safety risks are ranked the highest in terms of priority compared to the health and environmental risks in the steel manufacturing palnt. The administrative solutions were proposed to control and reduce the risks.
\end{abstract}

Keywords: Energy Trace and Barrier Analysis; Fuzzy Analytical Hierarchy Process; Risk Assessment; Steelmaking; TOPSIS 
dof: $10.21859 /$ johe.5.3.25

\title{
ارزيابى ريسك به روش رديابى انرزى و آناليز موانع (ETBA) با استفاده از TOPSIS
} در واحد فولادسازى شر كت تروه ملى صنعتى فولاد ايران

\author{
سميه بهببهانى'، سولماز دشتى ז.** \\ ا گروه مديريت محيط زيست (HSE)، واحد اهواز، دانشعاه آزاد اسلامى، اهواز، ايران .

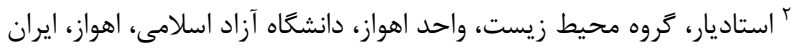 \\ * نويسنده مسئول: سولماز دشتى، كروه محيط زيست، واحد اهواز، دانشعاه آزاد اسلامى، اهواز، ايران. \\ ايميل:solmazdashti@gmail.com soolmazdashti@iauahvaz.ac.ir
}

\footnotetext{
جكيده

سابقه و هدف: صنعت فولادسازى و ريختهَّى يكى از يرمخاطرهترين صنايع موجود مىباشد؛ زيرا كاركران

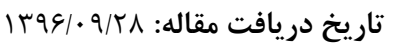

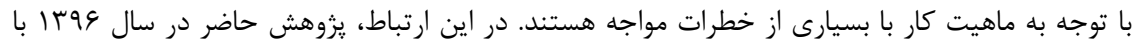

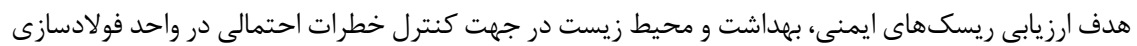

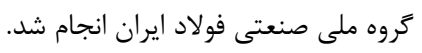

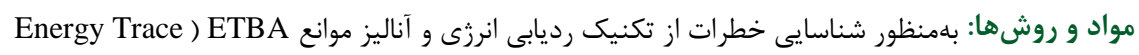

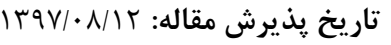
(and Barrier Analysis

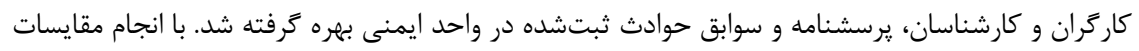

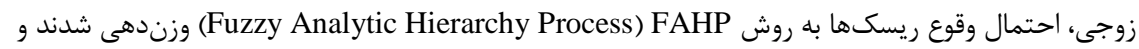

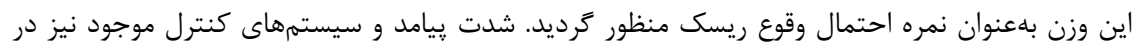

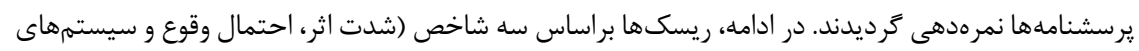
كنترل و نظارت) با روش Technique for Order Preference by Similarity to Ideal ) TOPSIS (Solution

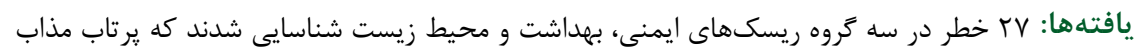

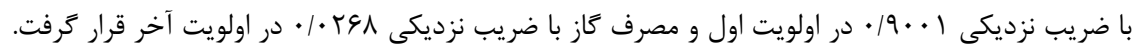

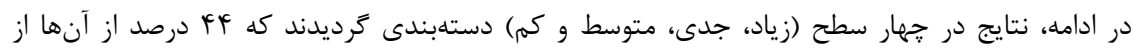

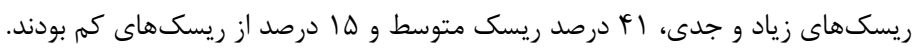

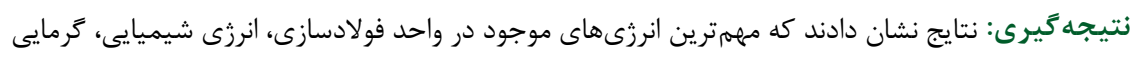

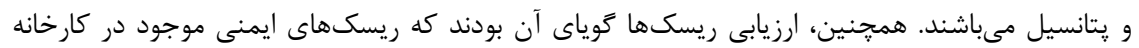

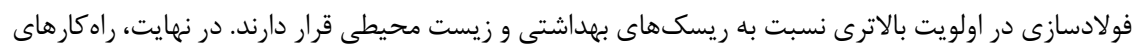
مديريتى جهت كنترل و كاهش ريسكها ارائه شد. يزشكى همدان محفوظ است.

جهت ييشگيرى از وقوع حوادث، ابتدا بايد دلايل آنها را ران بررسى و يردازش نمود تا از تكرار حوادث مشابه جلوكيرى شوى شود.

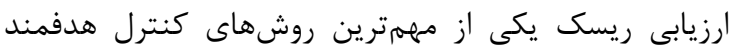
خطرات در صنعت مىباشد. در اين ارتباط، Pinto و و همكاران

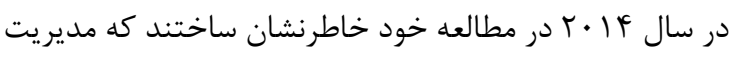
ريسك يكى از مهمترين ابزارهاى تعيين استراتزىهاى كنترل

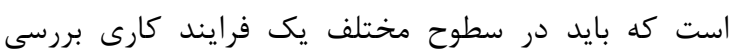

كارخانههاى فولاد از صنايعى هستند كه انجام روشهاى

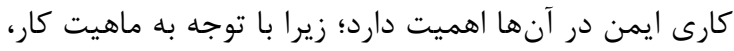

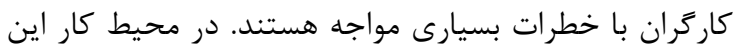
نوع صنعت هميشه خطر جراحات و سوختكى وجود دارد.

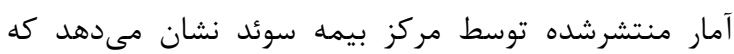
كارگران صنايع فلز در معرض بيشترين تعداد حوان موادث سالانه

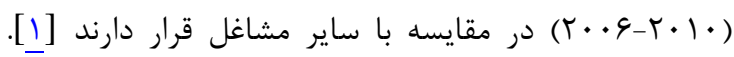


درخت خطا) برگرفته شده است. عدم وجود حفاظ يا هر گونه نقص

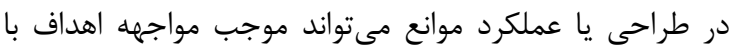
انرزىهاى خطرناك شده و در نهايت منجر به وقورع مردى يك حادثه كردد

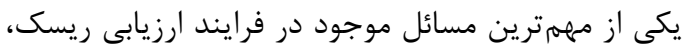

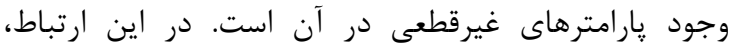

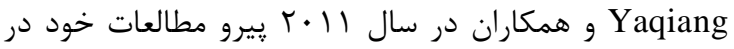

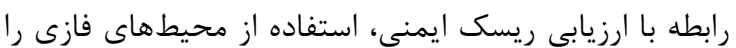

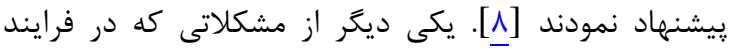

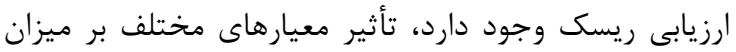

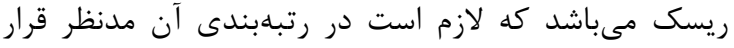

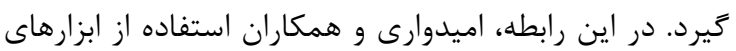
تصميم گيرى را بلهنوان يك روش مناسب براى تعيين ميزان

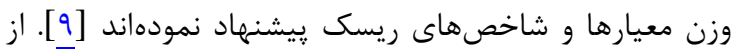

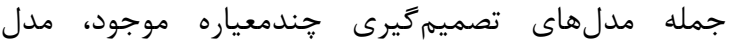

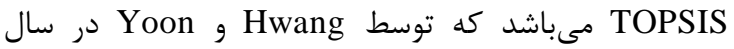

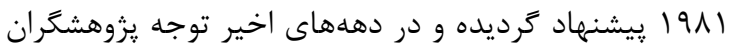
براى تصميم گيرىهاى بيجيده به اين روش معطوف شده است.

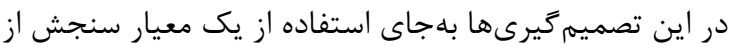

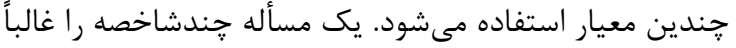

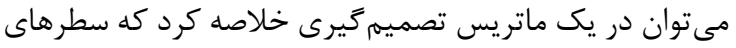

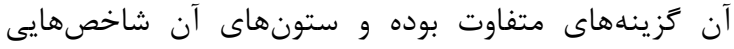

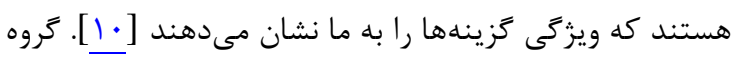

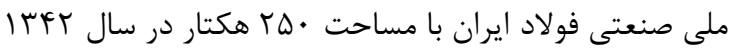

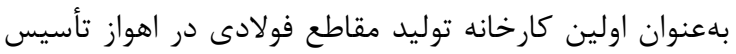

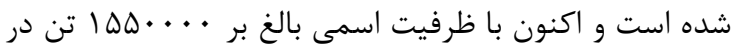

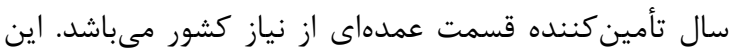
شركت از هشت واحد توليدى مستقل تشكيل شده است كه

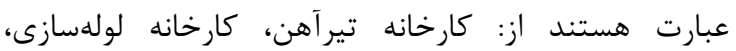
كارخانجات ميلگرد و مفتول، كارخانه نورد ميلگرد كوثر،

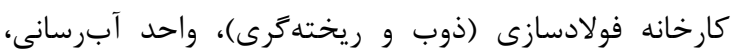

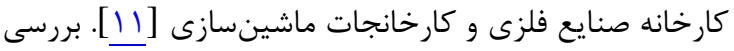

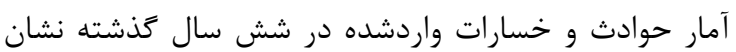
مىدهند كه حدود ب أ درصد از حريقهاى كارخانها و و و بيشتر حوادثى كه منجر به سوختگى و شكستتى اندى اندامها شدهاند،

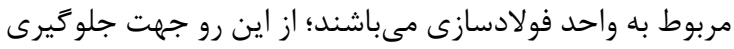

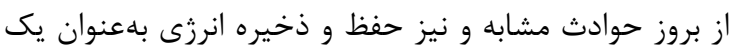

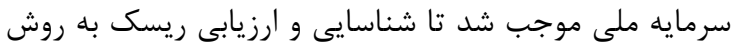

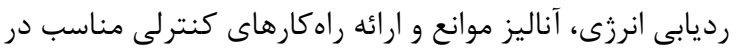

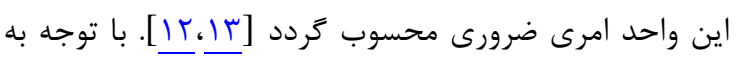

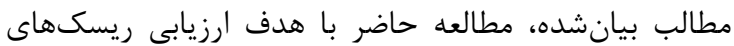
ايمنى، بهداشت و محيط زيست بهمنظور كنترل خطرات

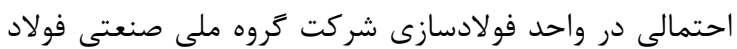
ايران انجام شد. با توجه به مطالب فوق، اهدافى كه در در اين
كردد [r]

يكى از روشهاى ارزيابى ريسك كه كاربرد زيادى دارد، ETBA را بهعنوان يك روش مناسب براى شناسايى خطر

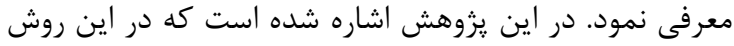

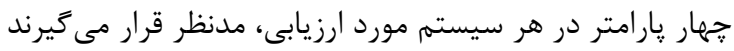

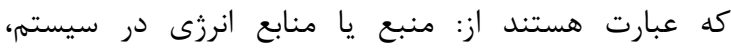

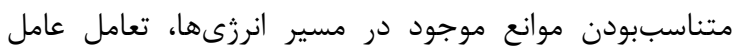

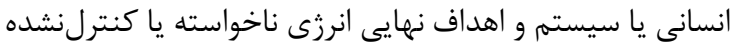

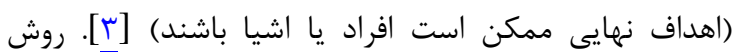

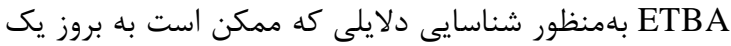
حادثه يا ضايعه كمك كنند، بسيار مفيد مى باشد [r]. Ericson بر اين باور است كه روش ETBA براى ارزيابى قابليت اطمينان و صحت روشهاى كنترلى خطرات كه در يك سيستم بهكار رفتهاند كاربرد دارد [ب]. در اين راستا، Santos Reyes و همكاران طى مطارد مالعهاى

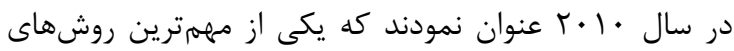

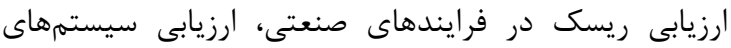

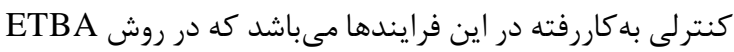

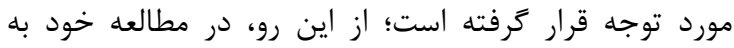

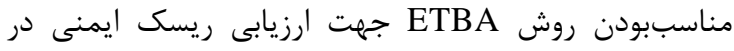

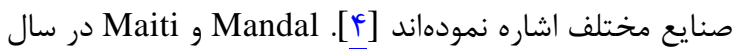

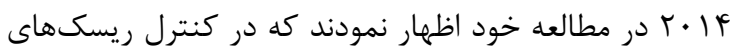

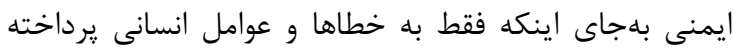

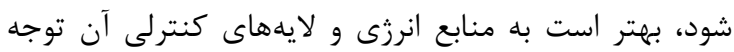

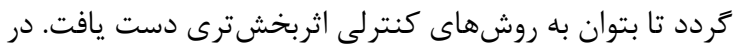

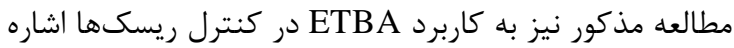
شده است. همجنين در اين مطالعه بيان شده است كه با كنترل منابع انرزى مى توان بخش بزرگى از حوادث را كنترل نمود [هـ].

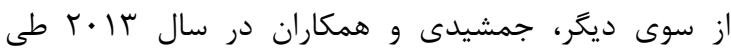

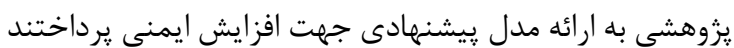

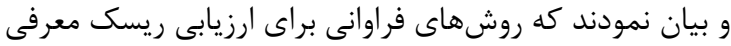

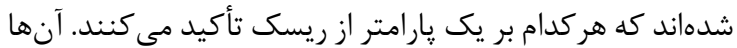

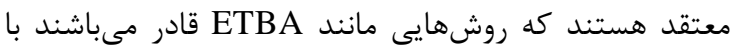
ارزيابى يك سيستم مانند سيستمهاى انرزى و رديابى انتقال مانئ ماند

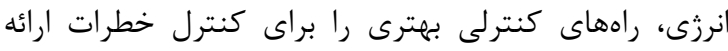

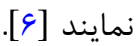

روش رديابى انرزى و واكاوى حفاظها (ETBA) يكى از سادهترين اشكال بسطيافته مدل انرزى مى باشد كه براساس اين اين

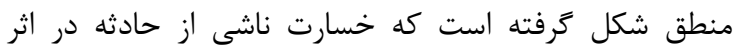

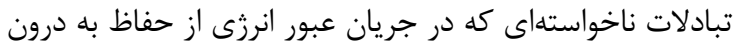

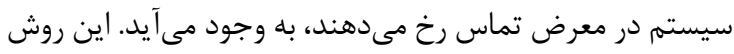

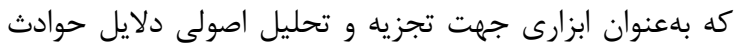

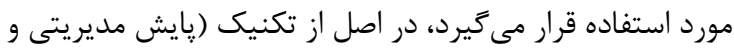


•

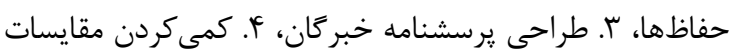

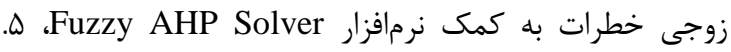

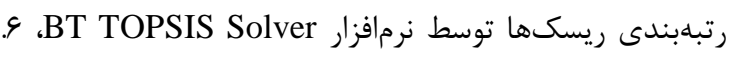

رتبهبندى سطوح ريسك به روش توزيع نرمال و V. لو ارائه راهكارهاى بهبود و كنترل ريسك رهاى بادئ سطح بالا.

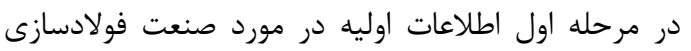

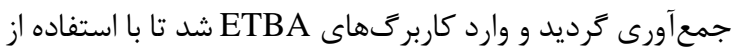
آن بتوان معيارها و ريسكهاى ايمنى، بهداشت و زيست محيطى وردي كارئ جامعه مورد مطالعه را تعيين نمود.

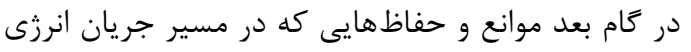

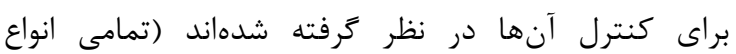
حفاظهاى فيزيكى و موانع مربوط به فرايند و نوع كار) شناسايى شدند. در مرحله سوم هدف، معيارها و زيرمعيارهاى مورد نياز تعيين

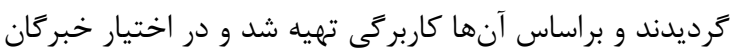

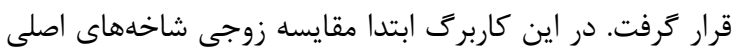
جهت تعيين اهميت و وزن شاخههاى اصلى نسبت به ديه يكديكر

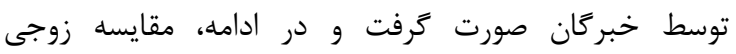
ريسكهاى هر شاخه بلصورت دو به دو با يكديكر انجام شد

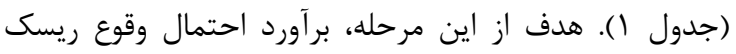

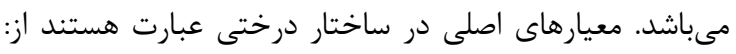

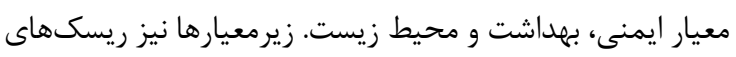
زيرمجموعه معيارهاى اصلى مى باشند.

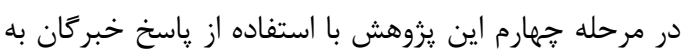

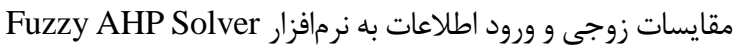
بلمنظور وزندهى به عبارات كلامى استفاده شد. فرايند تحليل

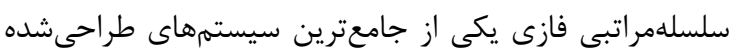

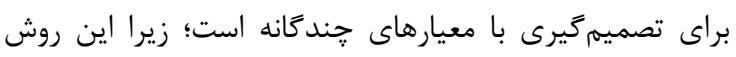

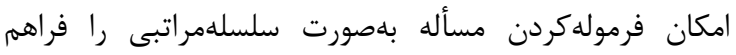

مطالعه مدنظر قرار گرفته است به شرح ذيل مىباشد: 1. شناسايى منابع مولد ريسك در واحد فولادسازى با استفاده

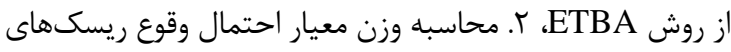

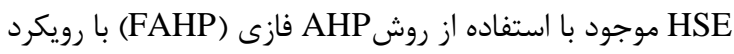

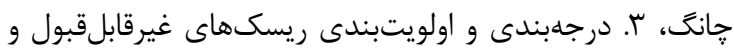
جنبههاى بارز در بخشهاى مختلف فولادسازى با استفاده از روش ورئدي

.TOPSIS

\section{مواد و روشها منطقه مورد مطالعه}

كارخانه فولادسازى به روش قوس الكتريكى در سال |هـا

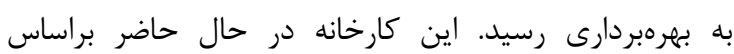

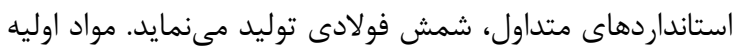

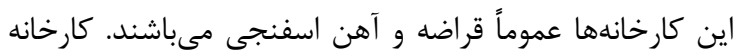
فولادسازى از سه بخش اصلى شامل: كوره قوس الكتريكى، كوره

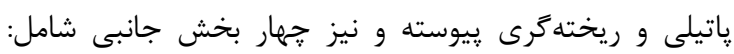

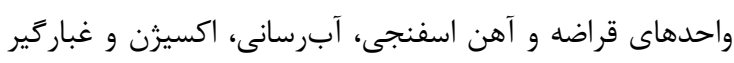

تشكيل شده است [بإئ.

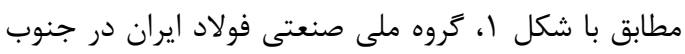

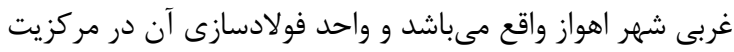

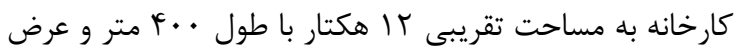

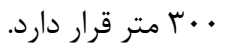

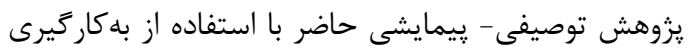

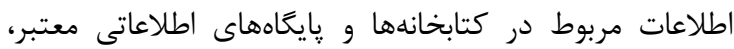
مصاحبه با كارشناسان و صاحبنظران و همجنين استفاده از

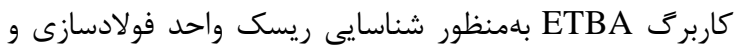

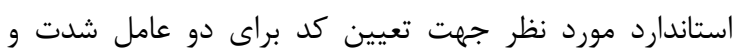
سيستم كنترل و نظارت روش اجرايى TUV Academy انجام

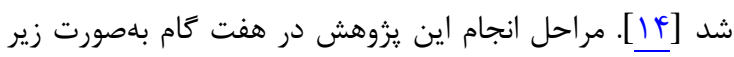

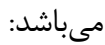

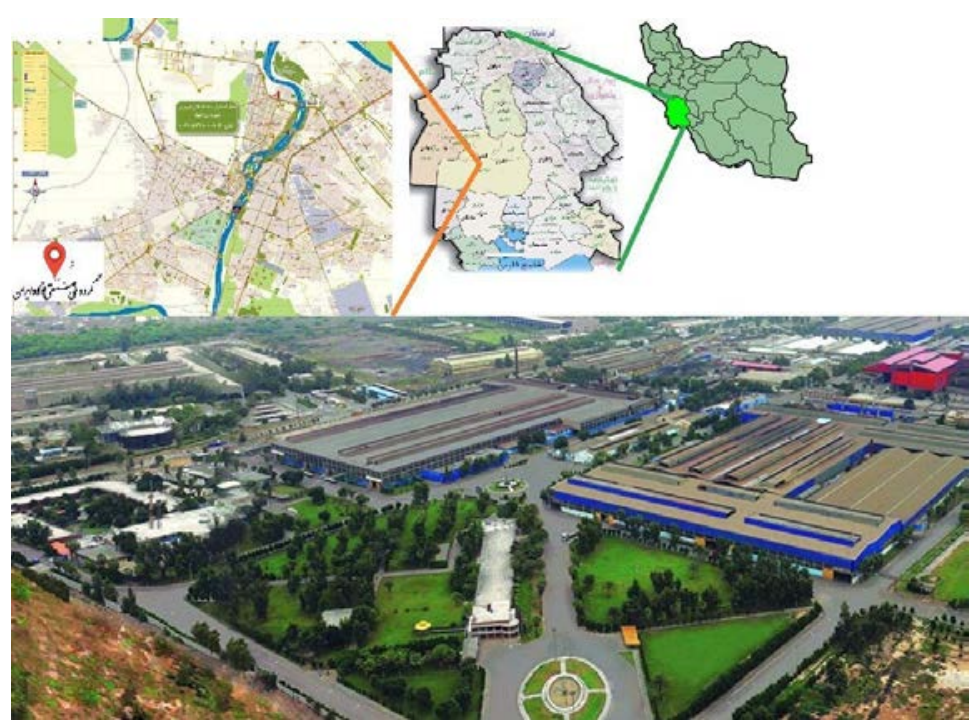

شكل ا: موقعيت مكانى كارخانه كروه ملى صنعتى فولاد ايران 
كار در صنعت فولادسازى بوده و با مفهوم ريسك و ايمنى آشنايى

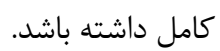

دركام بعد، ريسكها با سه معيار شدت، احتمال وقوع و

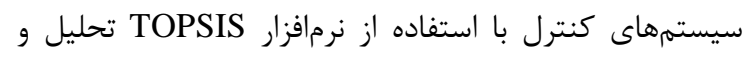

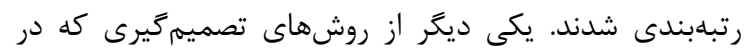

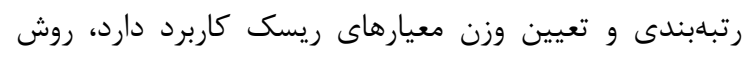
TOPSIS

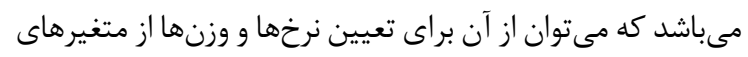

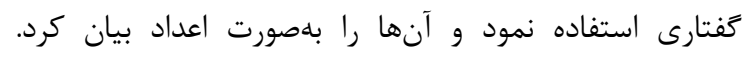

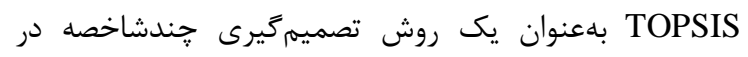

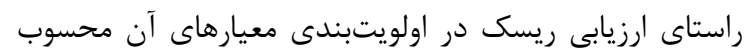

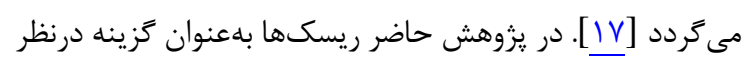

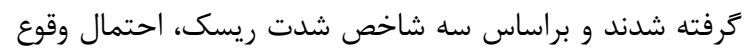
و سيستمهاى كنترل در ماتريس تصميمگيرى ريسكهاى حاصله رتبلابندى شدند.

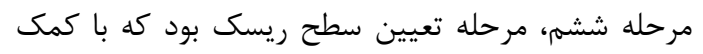

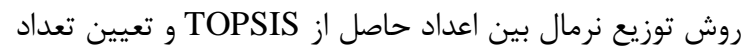

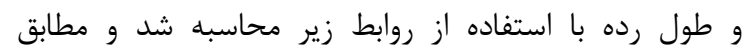

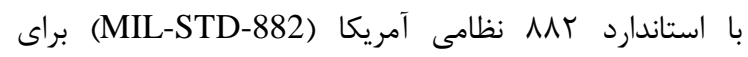
تقسيمبندى ريسكها به جهار سطح كم، متوسط، جدى و زياد
مىنمايد و از قابليت درنظر گرفتن معيارهاى مختلف كمى و كيفى

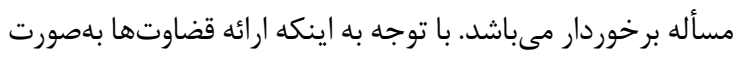

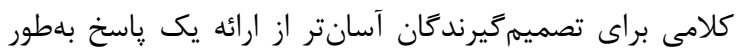

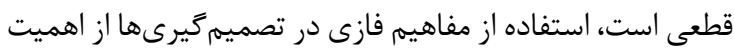

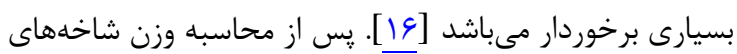

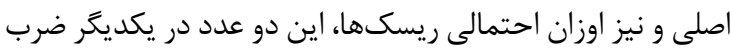

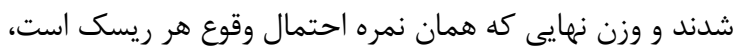

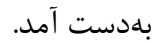

قسمت ديگرى از كاربرك به تعيين سطح يا ميزانى از خطر

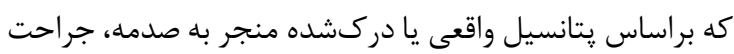

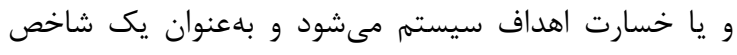

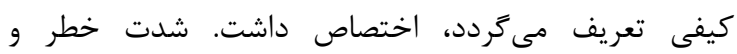

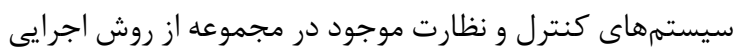

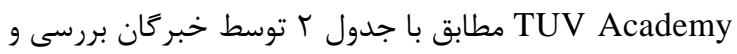
نمرهدهى شدند. جامعه آمارى اين يزوهش شامل سريرستان و متصديان واحد

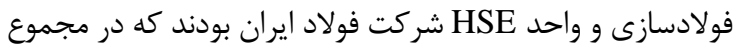
ش خبره بلصورت غيرموردى و براساس تخصص و شرايط

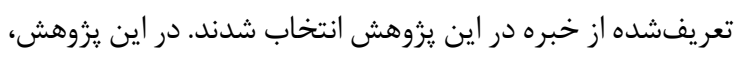
خبره به فردى اطلاق مى گردد كه داراى حداقل هفت سال سابقه

جدول ا: ترمهاى زبانى و دامنه فازى معادل آنها [هـ]

\begin{tabular}{|c|c|c|}
\hline توضيح & 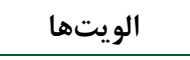 & معادل فازى \\
\hline كزينه يا شاخص i نسبت به شاخص j اهميت برابرى دارد و يا ارجحيتى نسبت به يكديخر ندارند. & ترجيح يكسان & $(1,1,1)$ \\
\hline بينابين & & $\left(\Gamma \cdot T_{\cdot} \cdot\right)$ \\
\hline كزينه يا شاخص i نسبت به شاخص j كمى مهمتر است. & كمى مرجح & $(\boldsymbol{f}, \mathrm{r}, \mathrm{r})$ \\
\hline بينابين & & $\left(\Delta, f^{\epsilon}, r\right)$ \\
\hline كزينه يا شاخص i نسبت به شاخص j مهمتر است. & بسيار مرجح & $\left(9 \cdot \omega, \varphi^{4}\right)$ \\
\hline بينابين & & 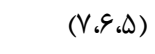 \\
\hline كزينه يا شاخص i داراى ارجحيت بسيار بيشترى نسبت به شاخص j است. & بسيار زياد مرجح & $(\wedge, \vee ، 9)$ \\
\hline بينابين & & $(৭ ، \wedge, \vee)$ \\
\hline كزينه i نسبت به شاخص j مطلقاً مهمهتر بوده و قابل مقايسه با آن نمىباشد. & كاملاً مرجح & $(9.9 .9)$ \\
\hline
\end{tabular}

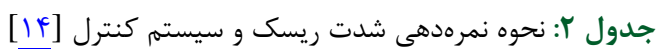

\begin{tabular}{|c|c|c|}
\hline شدت خطر & وضع كنترل هاى موجود & نمره \\
\hline مصدوميت يا بيمارى ناجيز/واردآورنده خسارت جزئى و ناراحتى خفيف براى انسان و & سيستمى براى كنترل و نظارً اثربخش مى وجاشد. & 1 \\
\hline 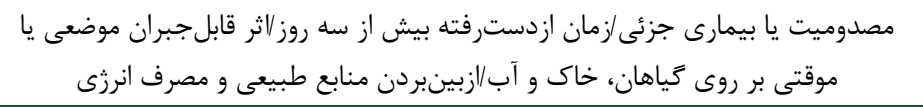 & سيستمى براى كنترل و نظارت موجود & $r$ \\
\hline مصدوميت يا بيمارى جدى/زمان ازدسترفته بيش از دو هفته/خسارتهاى غيرقابل جبران & سيستمى براى كنترل و نظارت موجود اما اثربخشى لازم را ندارد. & $\Delta$ \\
\hline مصدوميت يا بيمارى به همراه ازكارافتادگى اخسارتهاى غيرقابل جبران زيست محيطى با & سيستمى براى كنترل و نظارت وجود دارد؛ & $v$ \\
\hline حادثه فاجعهآميز، مرك نفر اخسارتهاى غيرقابل جبران زيست محيطى با اثرات بلندمدت & سيستمى براى كنترل و نظارت وجود ندارد. & 9 \\
\hline
\end{tabular}


كرديدند كه به تفكيك در جدول ب ارائه شدهاند.

مرزبندى گرديد [11].

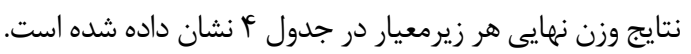

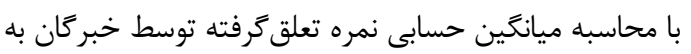

تعداد رده $=1+(3.3 \log N)$

رابطه |

دو يارامتر شدت ريسك و سيستمهاى كنترل موجود، دو يارامتر N

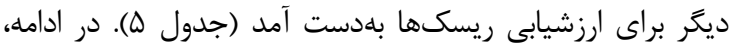
ضريب نزديكى ريسكها براساس سه شاخص ذكرشده محسئ رحاسبه

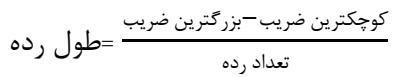

رابطه

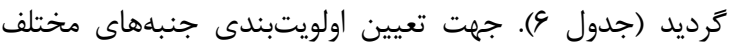

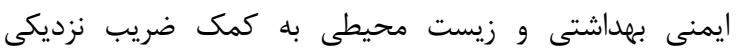
با شناسايى سطوح ريسك، در كام هفتم ييشنهادات اجرايى

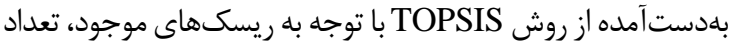

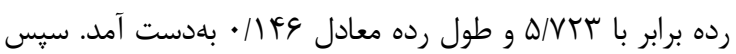
جهت كاهش سطح و كنترل هر جه بهتر ريسك دهاى با سطح زياد و جدى ارائه گرديد.

براساس ميزان ضريب نزديكى (CL) هر ريسك، ريسكها در جهار رده مطابق با جدول ع قرار كرفتند.

بافته.

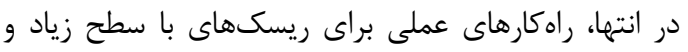

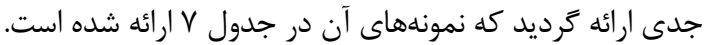

مطابق با نتايج حاصل از شناسايى خطرات، VV ريسك عمده

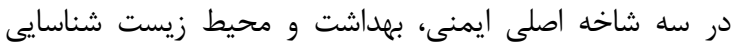

جدول بّ: ريسكهاى شناسايىشده

\begin{tabular}{|c|c|c|c|c|c|}
\hline حادثه & شاخه & حادثه & شاخه & حادثه & شاخه \\
\hline 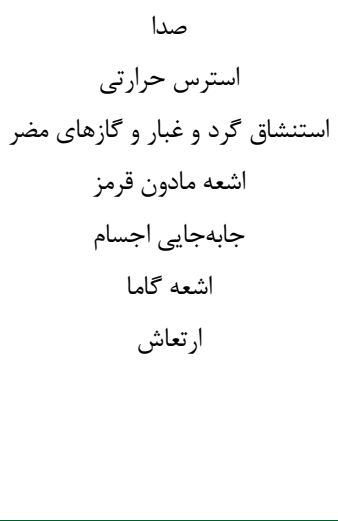 & $\begin{array}{l}\frac{3}{3} \\
3 \\
\frac{3}{3} \\
\frac{1}{y} \\
\frac{9}{y}\end{array}$ & 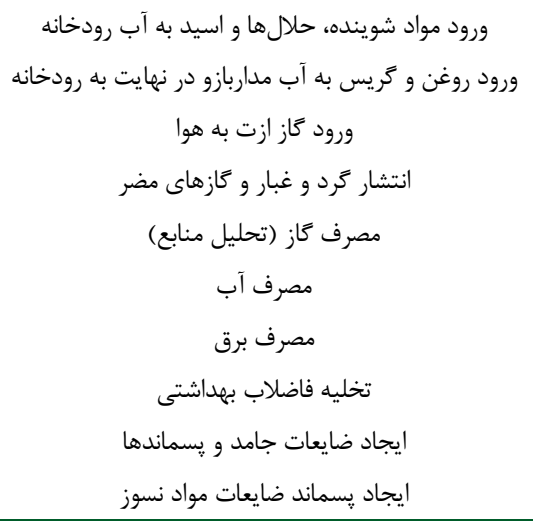 & $\begin{array}{l}3 \\
\frac{3}{3} \\
? \\
? 3\end{array}$ & 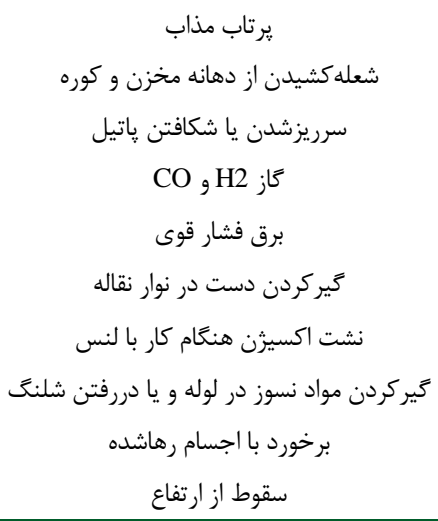 & $\bar{y}$ \\
\hline
\end{tabular}

جدول \&: نتايج اوزان نهايى هر زيرمعيار (احتمال وقوع ريسك)

\begin{tabular}{|c|c|c|c|c|c|c|c|c|c|c|c|}
\hline وزن نهايى & 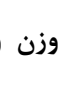 & ريسك & شاخه & 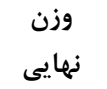 & وزن & ريسك & شاخه & 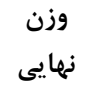 & وزن & ريسك & شاخه \\
\hline$\cdot \cdots \Delta$ & $.1 \cdot 19$ & صدا & \multirow{10}{*}{ 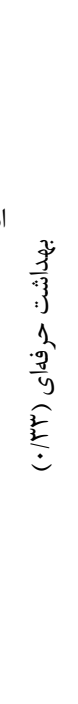 } & | | & $\cdot / 11$ & ورود مواد شوينده، حلال آبا و اسيد & & $\cdot / 109$ & $\cdot|r| \Lambda$ & ير يرتاب مذاب & \multirow{10}{*}{$\begin{array}{l}\overline{3} \\
\hat{3} \\
\stackrel{3}{\dot{n}}\end{array}$} \\
\hline$\cdot 1 \cdot 1$ & . & استرس حرارتى & & .1 .4 & ז & 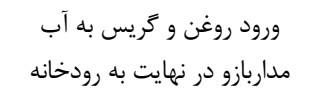 & & $\cdot / \cdot v \Delta$ & $\cdot / 10$ & شعله كشيدن از دهانه مخزن و & \\
\hline$\cdot 111$ & 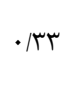 & استشاق كرد و غبار & & $\cdot \cdots \cdot \Delta$ & •...r & ورود كاز ازت به هوا & $3^{3}$ & $\cdot 1 \cdot \mathrm{V}$ & $\cdot / l^{\mathrm{F}}$ & سرريزشدن يا شكافتن پاتيل & \\
\hline .1 .14 &.$/ \cdot f$ & اشعه مادون قرمز & &. & $\cdot / \mathrm{VV}$ & انتشار كرد و غبار و كازهاى مضر & $?$ & $\cdot / 490$ & .1 .99 & كاز & \\
\hline.$/ \cdot r$ & $\cdot / \cdot \Lambda$ & جابهجايى اجسام & & $\cdot \cdot \omega$ & $\cdot / \cdot r$ & مصرف كاز (تحليل منابع) & $3^{3}$ & $\cdot 1 \cdot+\Delta$ & .1 .9 & برق فشار قوى & \\
\hline .1 .4 & $\cdot / 11$ & اشعه كاما & & 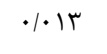 & $\cdot / \cdot f$ & مصرف آب & $\bar{\Sigma}$ & $\cdot 1 \cdot 4$ & $\cdot 1 \cdot 1$ & كيركردن دست در نوار نقاله & \\
\hline \multirow[t]{4}{*}{.$/ .4$} & $\cdot 1 \cdot \Delta$ & 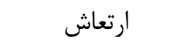 & & $.1 \cdot r_{4}$ & $\cdot / 1 \Delta$ & مصرف برق & & $.1 \cdot t$ & $\cdot|\cdot+|$ & نشت اكسيثن هنكام كار با لنس & \\
\hline & & & & $.1 . r$ & $\cdot 1 \cdot \Delta$ & تخليه فاضلاب بهداشتى & & $\cdot / \cdot 197$ & $.1 . r q f$ & كيركردن مواد نسوز در لوله و يا & \\
\hline & & & & $\cdot \cdot \cdot \Delta$ & $\cdot / \cdot r$ & ايجاد ضايعات جامد و يسماندها & & .1 .199 &.$/ .494$ & برخورد با اجسام رهاشده & \\
\hline & & & & $.1 \cdot Y r$ & $\cdot / l f$ & ايجاد پِماند ضايعات مواد نسوز & & $.1 \cdot \cdot 10$ & 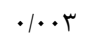 & سقوط از ارتفاع & \\
\hline
\end{tabular}


جدول ه: نمرات نهايى شدت ريسك و سيستمهاى كنترل موجود

\begin{tabular}{|c|c|c|c|c|c|c|c|c|c|c|c|}
\hline كنترل & 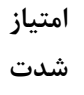 & ريسك & شاخه & كنترل & 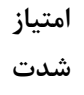 & ريسك & شاخه & كنترل & 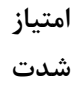 & 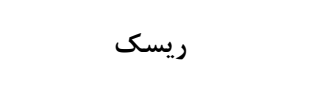 & شاخه \\
\hline$\Delta$ & V & صدا & \multirow{10}{*}{$\begin{array}{l}\frac{3}{3} \\
\vdots 3 \\
1 \\
\frac{9}{y} \\
\frac{3}{y}\end{array}$} & V & $\checkmark$ & ورود مواد شوينده، حلال ها و اسب به رودخه & \multirow{10}{*}{$\begin{array}{l}3 \\
3 \\
3 \\
3 \\
3\end{array}$} & V & 9 & يرتاب مذاب & \\
\hline V & $\Delta$ & استرس حرارتى & & 9 & V & مداربازو در نهايت بـ به رودخانه & & V & 9 & شعله كشيدن از دهانه مخزن و & \\
\hline$\Delta$ & v & استنشاق كرد و غبار و & & 9 & r & ورود كاز ازت به هوا & & $r$ & v & سرريزشدن يا شكافتن پاتيل & \\
\hline$r$ & r & اشعه مادون قرمز & & $r$ & V & انتشار كرد و غبار و كازهاى & & 1 & V & كاز & $3^{:}$ \\
\hline$\Delta$ & r & جابهجايى اجسام & & 1 & r & مصرف گاز (تحليل منابع) & & r & 9 & برق فشار قوى & $y$ \\
\hline 1 & $\Delta$ & اشعه كاما & & r & r & مصرف آب & & $\Delta$ & v & كيركردن دست در نوار نقاله & \\
\hline \multirow[t]{4}{*}{$\Delta$} & r & ارتعاش & & r & r & مصرف برق & & $\Delta$ & $\Delta$ & نشت اكسيرن هنكام كار با لنس & \\
\hline & & & & $\Delta$ & r & تخليه فاضلاب بهداشتى & & V & 9 & كيركردن مواد نسوز در لوله يا & \\
\hline & & & & r & r & ايجاد ضايعات جامد و يسماندها & & v & v & برخورد با اجسام رهاشده & \\
\hline & & & & $\Delta$ & V & ايجاد يسماند ضايعات مواد & & $r$ & 9 & سقوط از ارتفاع & \\
\hline
\end{tabular}

جدول 9: ضريب نزديكى ريسكها براساس تكنيك TOPSIS و سطحبندى آنها

\begin{tabular}{|c|c|c|c|c|}
\hline سطح ريسك & فراوانى ريسكها & رده ريسك (دامنه & ضزديكى & 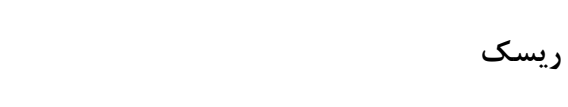 \\
\hline زياد (HIGH) & 1 & $\cdot / N Q_{-} \cdot / 9 \cdot r$ & $.19 \cdots 1$ & ير تاب مذاب \\
\hline زياد (HIGH) & 1 & $\cdot / \Delta \wedge r-\cdot / V Y q$ & .19019 & استنشاق گرد و غبار و كازهاى مضر \\
\hline \multirow{4}{*}{$\begin{array}{c}\text { جدى } \\
\text { (SERIOUS) }\end{array}$} & \multirow{4}{*}{ r } & \multirow{4}{*}{$\cdot / 4 r \Lambda-\cdot / \Delta \lambda r$} & . $|\Delta M F|$ & استرس حرارتى \\
\hline & & & .10119 & برخورد با اجسام رهاشده \\
\hline & & & $\cdot|4 \& V|$ & نشت اكسيرن هنعام كار با لنس \\
\hline & & & - /ArAk & ورود روغن و گر يس به آب مدارباز و در نهايت به رودخانه \\
\hline \multirow{6}{*}{$\begin{array}{c}\text { جدى } \\
\text { (SERIOUS) }\end{array}$} & \multirow{6}{*}{4} & \multirow{6}{*}{$\cdot / r q 4-\cdot / 4 r \Lambda$} & $\cdot|f| V$ & كيركردن مواد نسوز در لوله و يا دررفتن شلنگ \\
\hline & & & $. / 49 \mid \mathrm{V}$ & ورود مواد شوينده، حلالها و اسيد به آب رودخانه \\
\hline & & & $\cdot / T \Delta 94$ & شعله كشيدن از دهانه مخزن و كوره \\
\hline & & & $\cdot / r \Delta \cdot \Lambda$ & سقوط از ارتفاع \\
\hline & & & •/MTtY & سرريزشدن يا شكافتن پاتيل \\
\hline & & & $\cdot \operatorname{lr}$ & ورود كاز ازت به هوا \\
\hline \multirow{11}{*}{$\begin{array}{c}\text { متوسط } \\
\text { (MEDIUM) }\end{array}$} & \multirow{11}{*}{11} & \multirow{11}{*}{$\cdot / 149-\cdot / 494$} & $\cdot /$ KAFV & ايجاد يسماند ضايعات مواد نسوز \\
\hline & & & $\cdot /$ TYYG & ي يركردن دست در نوار نقاله \\
\hline & & & $\cdot / 4 R I T$ & برق فشار قوى \\
\hline & & & $\cdot / r \Delta \Delta V$ & جابهجايى اجسام \\
\hline & & & $\cdot /$ TATF & انتشار ترد و غبار و كازهاى مضر \\
\hline & & & - RTYV & صدا \\
\hline & & & $\cdot / T r \Lambda$ & اشعه تاما \\
\hline & & & . ITrTV & ار ارتعاش \\
\hline & & & . ITHTV & تخليه فاضلاب بهداشتى \\
\hline & & & $\cdot / I V F A$ & مصرف برق \\
\hline & & & $\cdot|| \Delta \& \mid$ & كاز H2 و \\
\hline \multirow{4}{*}{ كم (LOW) } & \multirow{4}{*}{ r } & \multirow{4}{*}{$\cdot-\cdot / 149$} & . MrYs & مصرف آب \\
\hline & & & . MrYS & اشعه مادون قرمز \\
\hline & & & $\cdot|1 \cdot \Delta|$ & ايجاد ضايعات جامد و پسماندها \\
\hline & & &.$/ . r \& \Lambda$ & مصرف گاز (تحليل منابع) \\
\hline
\end{tabular}


جدول V: راهكارهاى عملى جهت بهبود سطح ريسكها

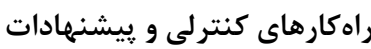

حادثه

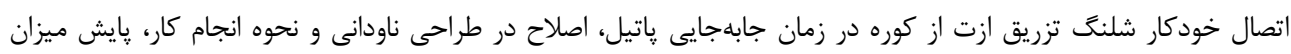

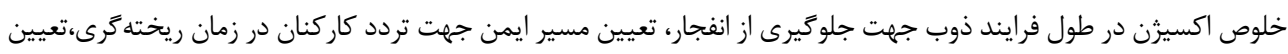
بر تاب مذاب

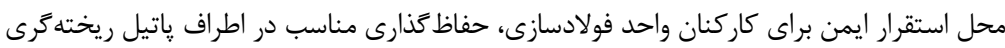

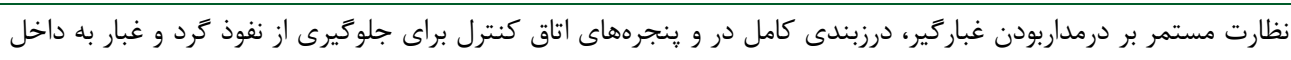

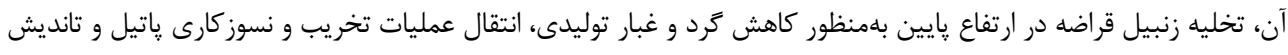

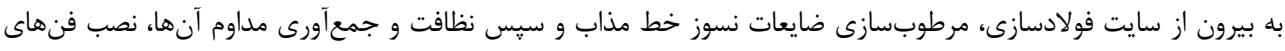

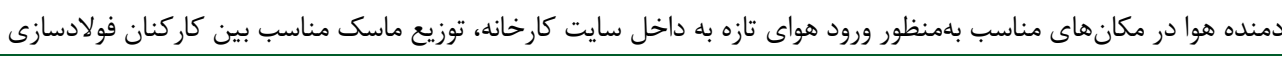

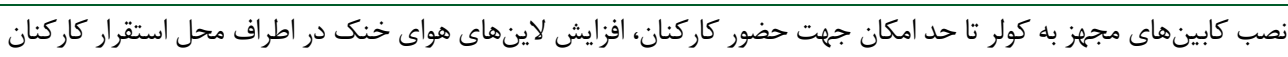

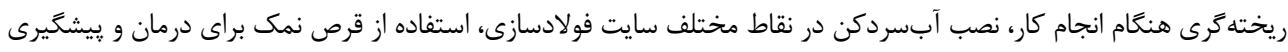

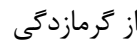

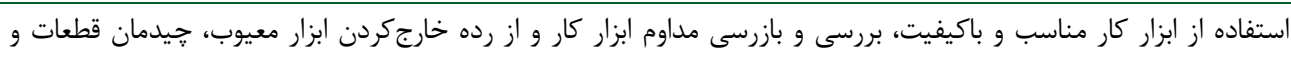

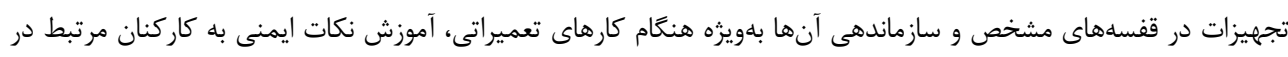

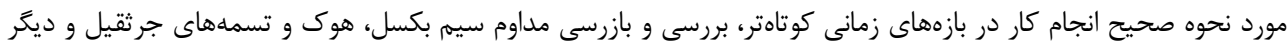

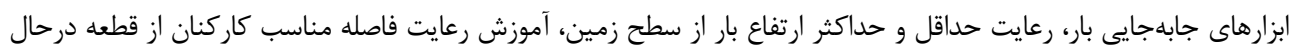

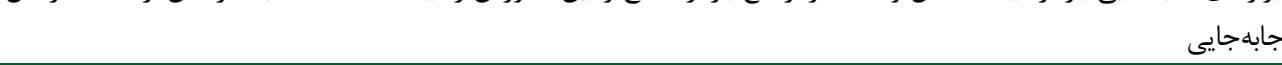

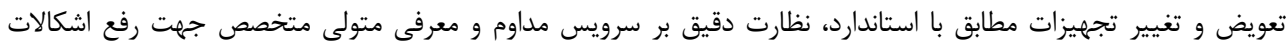

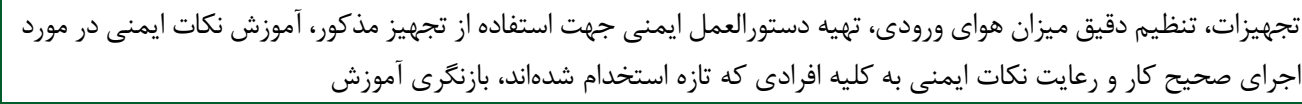

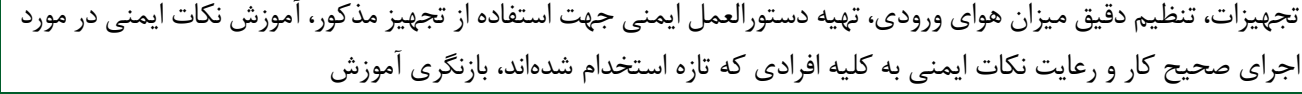

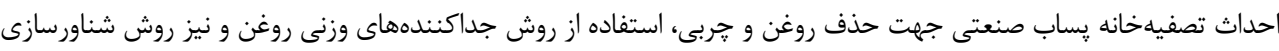

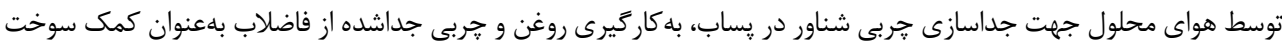

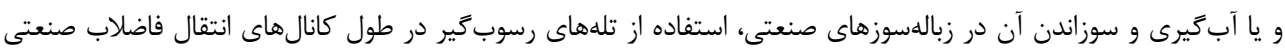

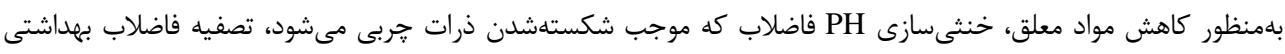

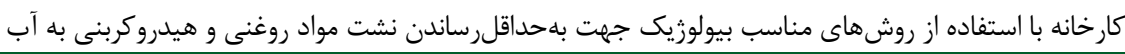

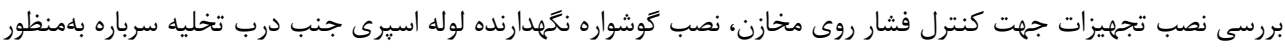

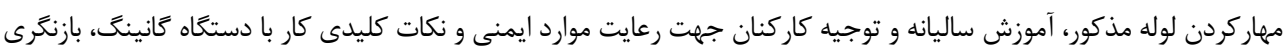

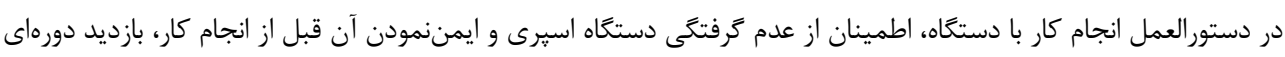

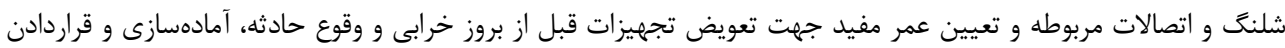

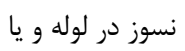

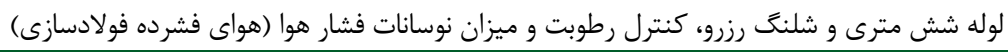

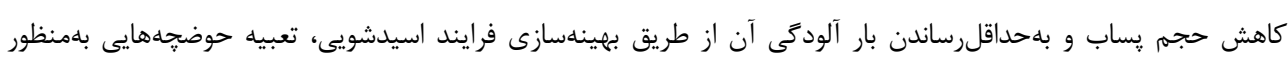

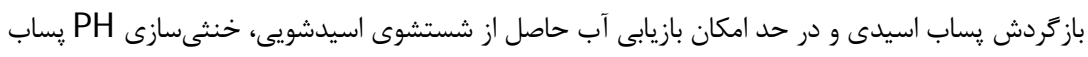

ريسكها براساس ضريب نزديكى حاصل از TOPSIS

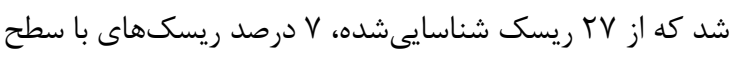

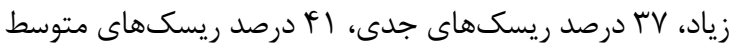
و ها درصد ريسكهاى با سطح كم بودند.

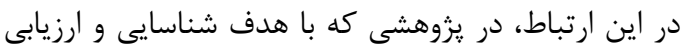
ريسك به روش ETBA در يك صنعت ريخته كرى (فولادسازى)

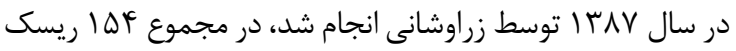

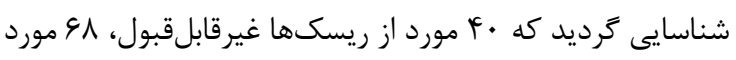

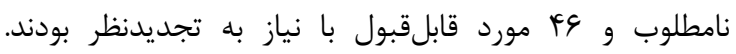

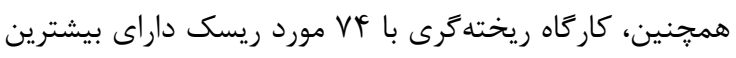

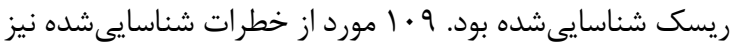

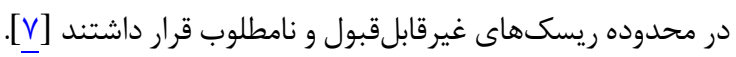

در طول • له سال كذشته تغييرات قابل توجهى در مواد،

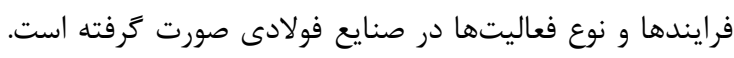

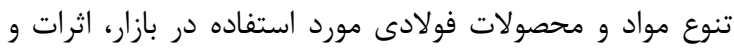
يبامدهاى محيطى و اجتماعى و حوادث شيميايى در اين صنايع

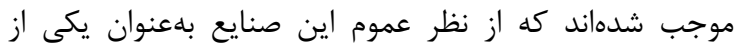

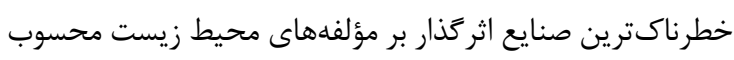

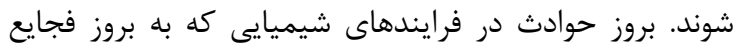

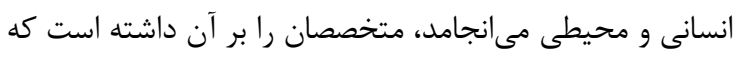

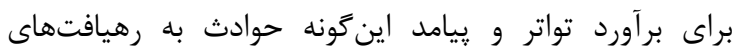

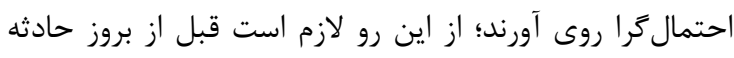

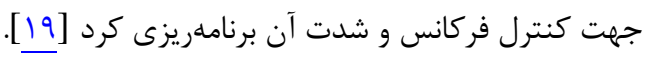

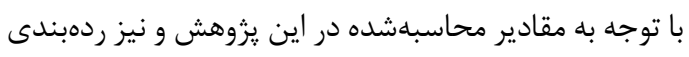


و معمولاً در تمامى فرايندهاى يروسه توليد فولاد انجام مى شود. با توجه به حضور ماده سوختنى، اكسيزن و شعله در فرايند

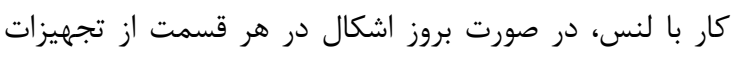
برشكارى از جمله مسير اكسيرن، كاز و ويا نازل، احتمال آتشسوزى و سوختكى افراد انجامدهنده كار بسيار بالا مى باشدي.

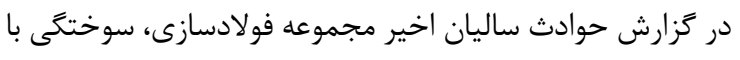

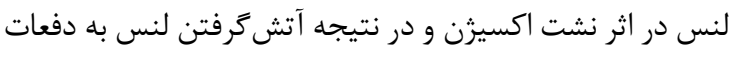

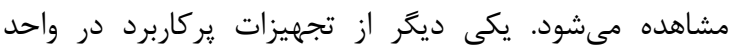

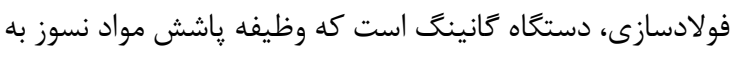

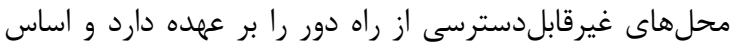

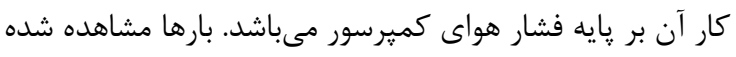
است كه به دليل عدم نظارت صحيح بر وسايل مربوطه مانند

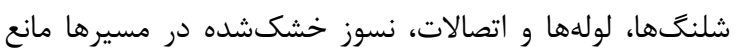

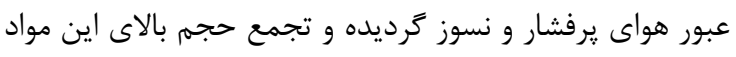

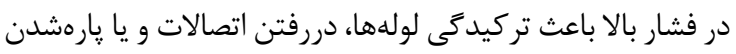

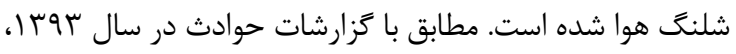

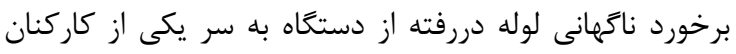
منجر به فوت وى گرديد.

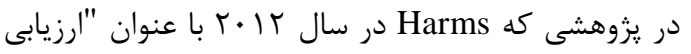
ريسك در يك واحد ريختهرى در كارخانه فولاد در شمال

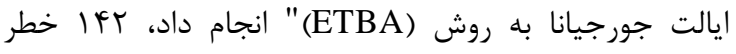

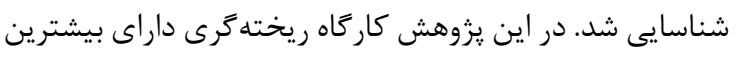

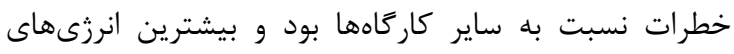

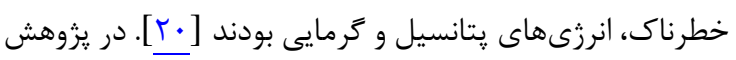

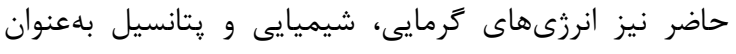

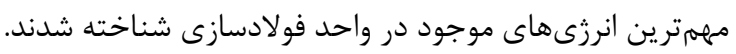

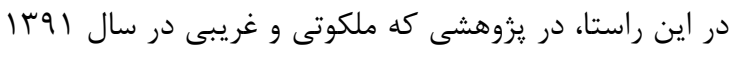

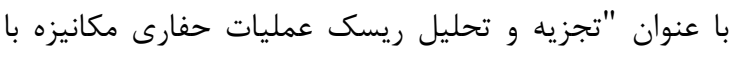

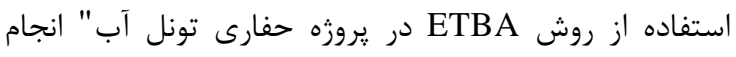

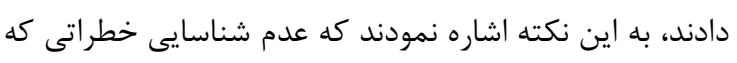

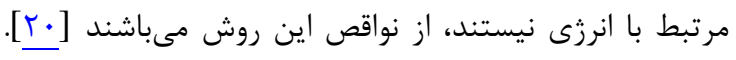

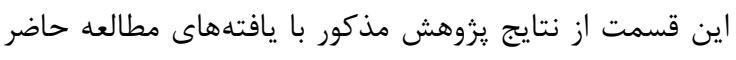

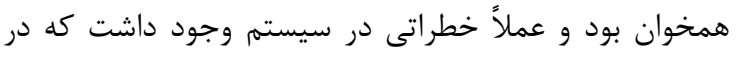

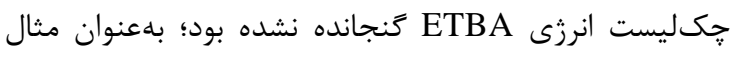
ريسكهاى زيست محيطى و بهداشتى و يا خطرات ايمنى مانند

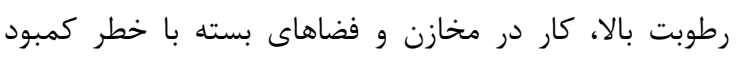

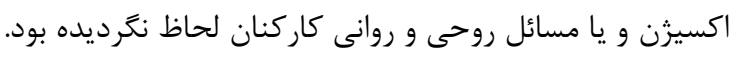

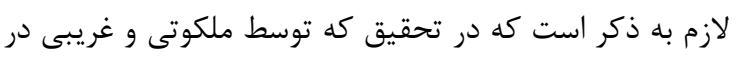

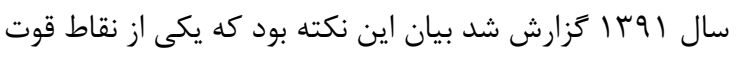

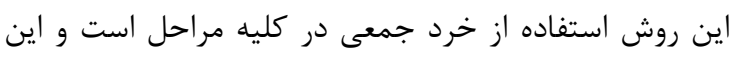

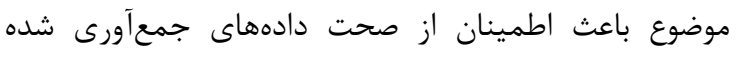

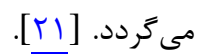
ورود روغن و گريس به آب رودخانه نيز كه در اثر فعاليتهاى
نتايج مطالعه زراوشانى و همكاران و همجنين يزوهش حاضر

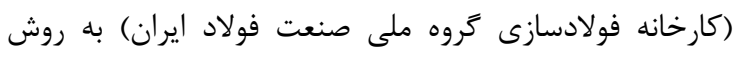

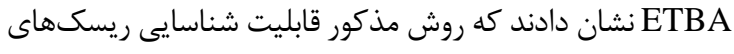
موجود در صنعت ريخته

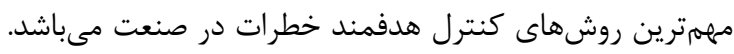

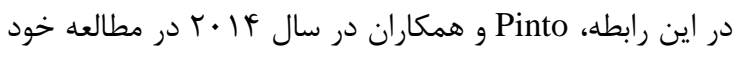

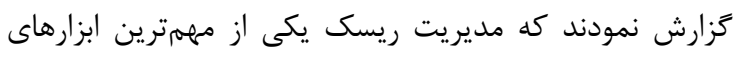

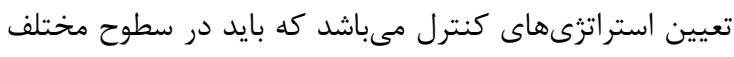

يكى فرايند كارى بررسى گردد [IV]

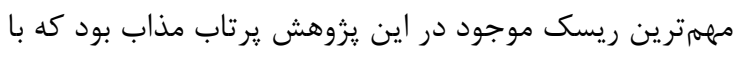

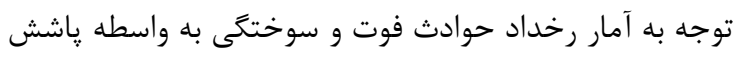

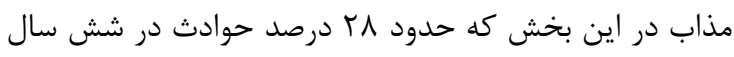

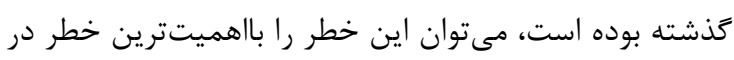

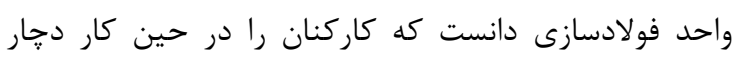

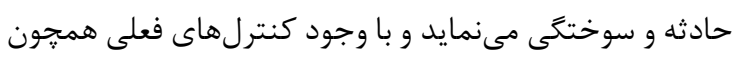

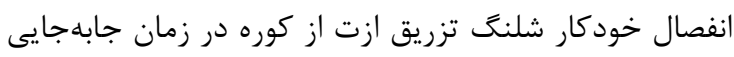

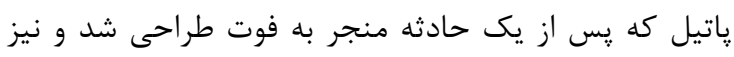

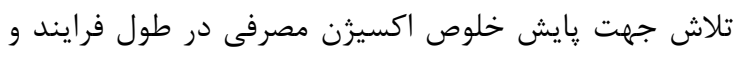

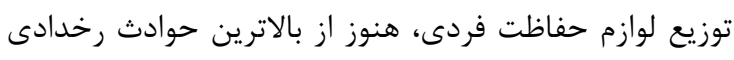

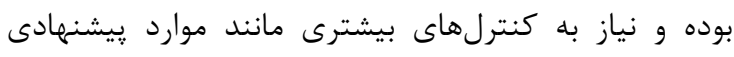

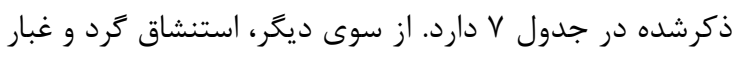

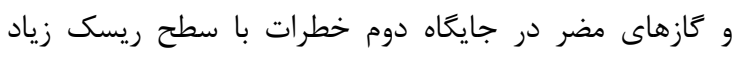

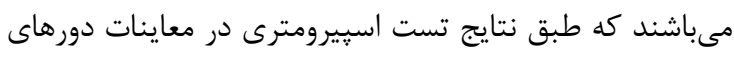
طب صنعتى، اختلال در تنفس و كاهش ظرفيت تنفسى و حجم

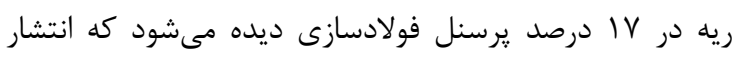

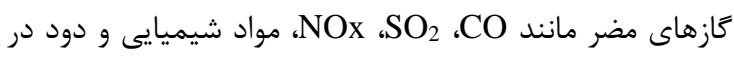
طول فرايندهاى توليد مذاب و ذوب قراضه و و آليازئسازى ايجاد

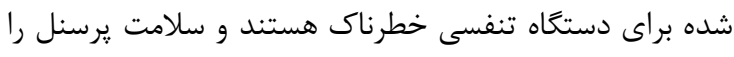

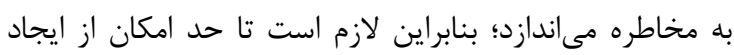
آنها جلوكيرى كرده و يا به بيرون محوطه كار انتقالشان داد.

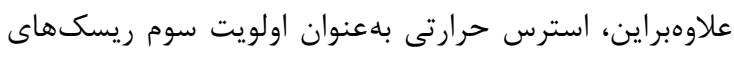

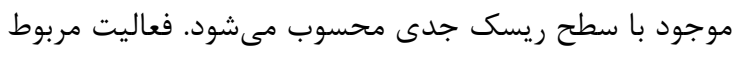

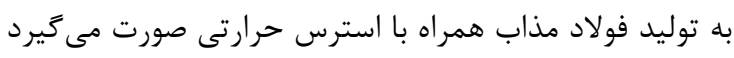
و امكان تماس با بدن و سوختكى را براى كاركنان توليد كوره

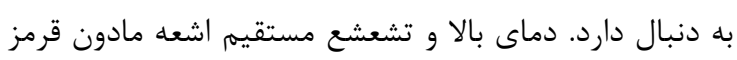

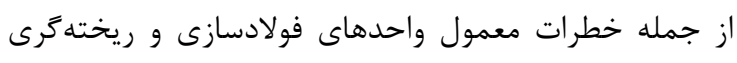

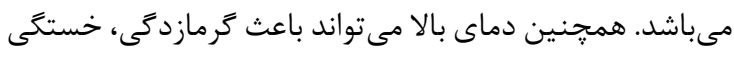

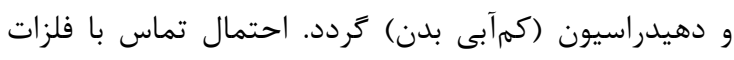

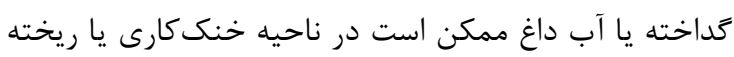

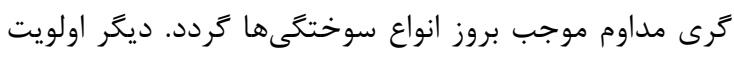

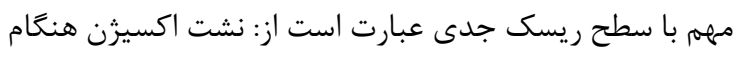

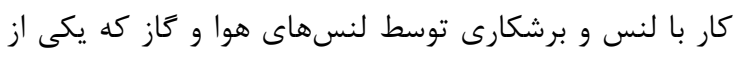

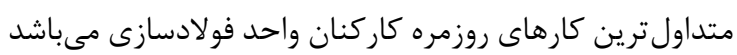


با موضوع مشابه و همجنين استفاده از روشهاى يزوهشى

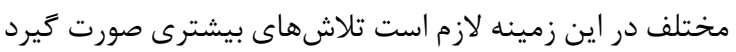

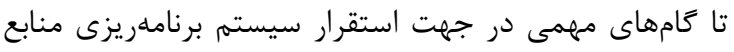

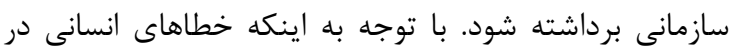
روش ETBA لحاظ نمىشوند، توصيه بر آن است كه همراه با بأن اين روش از ساير روشهاى ارزيابى ريسك كه خطاهاى انسانى

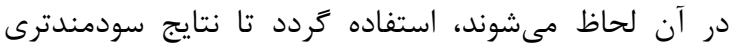

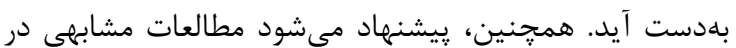

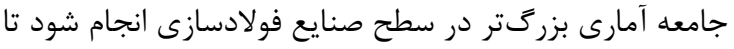

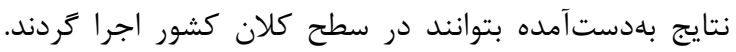

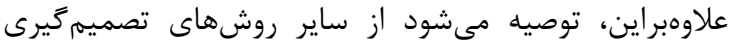

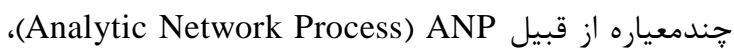
(Simple Additive Weighting) SAW روشهاى تخصصى ارزيابى ريسك استفاده گردد. تشك و قلروانى يروهشگران اين مقاله نهايت سياس خود ران را از جناب آقاى

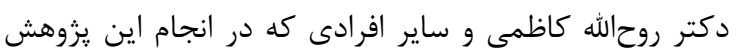
يارى نمودند؛ ابراز مى دارند.

\section{REFERENCES}

1. Nordlof H, Wiitavaara B, Winblad U, Wijk K, Westerling R. Safety culture and reasons for risk-taking at a large steelmanufacturing company: Investigating the worker perspective. Saf Sci. 2015;73:126-35. DOI: 10.1016/j.ssci.2014.11.020

2. Pinto A. QRAM a qualitative occupational safety risk assessment model for the construction industry that incorporate uncertainties by the use of fuzzy sets. Saf Sci. 2014;63:57-76. DOI: 10.1016/j.ssci.2013.10.019

3. Ericson A. Hazard analysis techniques for system safety. $3^{\text {rd }}$ ed. New Jersey: John Wiley \& Sons; 2005. P. 335-51.

4. Santos-Reyes J, Alvarado-Corona R, Olmos-Peña S. Learning from Tabasco's floods by applying MORT. Saf Sci. 2010;48(10):1351-60. DOI: 10.1016/j.ssci.2010.05.008

5. Mandal S, Maiti J. Risk analysis using FMEA: fuzzy similarity value and possibility theory based approach. Exp Syst Appl. 2014;41(7):3527-37. DOI: 10.1016/j.eswa.2013.10.058

6. Jamshidi A, Yazdani-chamzini A, Yakhchali SH, Khaleghi S. Developing a new fuzzy inference system for pipeline risk assessment. J Loss Prev Proc Ind. 2013;26(1):197-208. DOI: 10.1016/j.jlp.2012.10.010

7. Zaroushani V, Varriani AS, Ayati SA, Nikpey A. Risk assessment in a foundry unit by energy trace and barrier analysis method (ET\&BA). Iran Occup Health. 2010;6(4):714. [Persian]

8. Branco DA, Rathmann R, Borba BS, de Lucena AF, Szklo A, Schaeffer R. A multicriteria approach for measuring the carbon-risk of oil companies. Energy Strategy Rev. 2012;1(2):122-9. DOI: 10.1016/j.esr.2012.06.002

9. Yaqiong L, Man LK, Zhang W. Fuzzy theory applied in quality management of distributed manufacturing system: a literature review and classification. Eng Appl Artificial Intellig. 2011;24(2):266-77. DOI: 10.1016/j.engappai.2010.10.008

10. Omidvari M, Mansouri N, Nouri J. A pattern of fire risk assessment and emergency management in educational center laboratories. Saf Sci. 2015;73:34-42. DOI: 10.1016/j.ssci. 2014.11.003

11. Taylan O, Bafail AO, Abdulaal RM, Kabli MR. Construction projects selection and risk assessment by fuzzy AHP and fuzzy TOPSIS methodologies. Appl Soft Comput. 2014;17:105-16. DOI: 10.1016/j.asoc.2014.01.003
مربوط به آبرسانى به علت انتشار مواد روغنى در آب و در يى آى

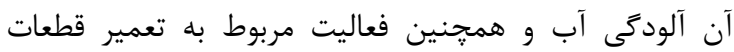

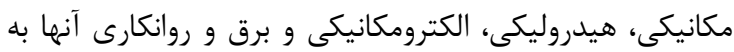

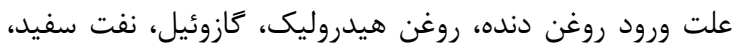

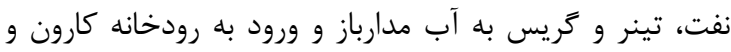
متعاقب آن آلودگى آب نيز در سطح بـ ريسك بالا قرار داشته و

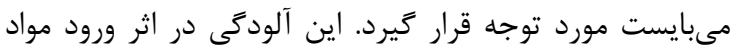

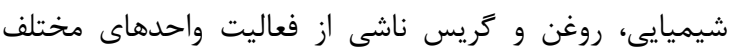

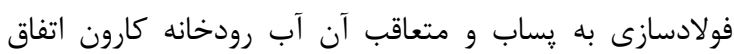
ميافتد [Tr]

\section{نتيجه كيرى}

نتايج نشان دادند كه مهممترين انرزىهاى موجود در واحد

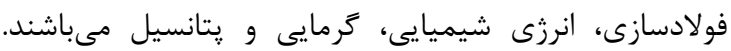

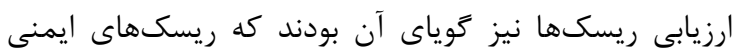

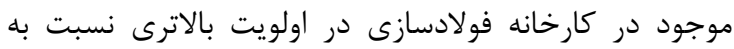
ريسكهاى بهداشتى و زيست محيطى قرار دارند. اين نتايج

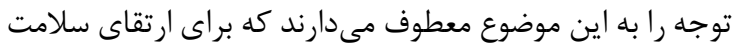

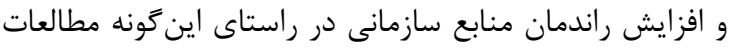

12. Kaabzadeh S, Baninaeeme S, Mohri M, Baninaeeme M. Risk analysis \& management of Iran national steel company by William fine method. In: The First National Conference Planning, Conservation, Environmental Protection, Sustainable Development; Hamadan, Iran; 2014. [Persian]

13. Steelmaking plant. Steel plant was put into operation in 1972 by electric arc method. Iran National Steel Industrial Group. Available at: URL: http://insig.org/en/factories-andproducts/factories/steelmaking-plant; 2018.

14. Eshghi B. Executive method of occupational health and safety. Tehran: Tuv Nord Academy; 2012. [Persian]

15. Habibi A, Eizadiar S, Sarafrazi A. Fussy method in decision making. Rasht: Katibe Gil; 2014. [Persian]

16. Malekhoseini F. Environmental risk assessment of Dena protected area by using multiplicriteria decision making. [Master Thesis]. Ahvaz: Islamic Azad University; 2015. [Persian]

17. Rahmani S, Omidvari M. Assessing safety risk in electricity distribution processes using ET \& BA improved technique and its ranking by VIKOR and TOPSIS models in fuzzy environment. Health Saf Work. 2016;6(1):1-2. [Persian]

18. Mil-std-882d standard practice for system safety program requirement. New York: Department of Defence Standard Practice USA; 2010. P. 15-8.

19. Allahyari T. Risk analysis and assessment in chemical processes. Ghom: Nejabat; 2006. [Persian]

20. Zaroushani V, Varriani AS, Ayati SA, Nikpey A. Risk assessment in a foundry unit by energy trace and barrier analysis method (ETBA). Iran Occupat Health. 2010;6(4):714. [Persian]

21. Malakouti J, Gharibi V. Risk analysis of automated excavation operations by energy trace \& barrier analysis method. Iran Occupat Health. 2013;10(2):87-98. [Persian]

22. Khodabakhshi L, Jaafarzadeh haghighi N. determining quality of air indoor and outdoor in viewpoint of suspended particles in beam rolling and armature rolling units of Iran national industrial group in Ahvaz. [Master Thesis]. Ahvaz: Islamic Azad University; 2006 [Persian] 